\title{
PENGARUH AGEN SOSIALISASI DAN IKLAN TV TERHADAP SIKAP DAN PERILAKU MENYIKAT GIGI PADA SISWA SEKOLAH DASAR
}

\author{
Zikri $^{\left.{ }^{*}\right)}$, Lilik Noor Yuliati ${ }^{2}$, Megawati Simanjuntak ${ }^{2}$ \\ ${ }^{1}$ Program Studi Manajemen dan Bisnis, Institut Pertanian Bogor, Bogor 16151, Indonesia \\ ${ }^{2}$ Departemen IImu Keluarga dan Konsumen, Fakultas Ekologi Manusia, Institut Pertanian Bogor, \\ Bogor 16680, Indonesia \\ ${ }^{*}$ E-mail: Zikkri75@gmail.com
}

\begin{abstract}
Abstrak
Penelitian ini bertujuan untuk menganalisis pengaruh sosialisasi dari teman sebaya, keluarga/orang tua, sekolah, dan iklan Televisi terhadap sikap dan perilaku menyikat gigi. Penelitian dilakukan pada dua kelompok siswa sekolah dasar kelas lima di Tangerang Selatan yang telah terpapar dan yang belum terpapar oleh Program sekolah sehat yang dipilih dengan menggunakan multistage sampling. Jumlah total responden adalah 240 orang siswa dari empat sekolah yang berbeda dengan masing-masing kelompok terdiri atas 120 orang siswa dari dua sekolah yang dipilih dengan menggunakan pendekatan quota sampling. Data dikumpulkan dengan teknik pelaporan diri dan dianalisis menggunakan analisis deskriptif, uji beda, dan Structural Equation Modeling-Partial Least Square (SEM-PLS). Hasil penelitian menunjukkan adanya perbedaan yang signifikan antara kedua kelompok siswa pada variabel sosialisasi dari teman sebaya, keluarga/orang tua, sosialisasi iklan TV, sikap, dan perilaku menyikat gigi. Hasil penelitian juga menunjukkan bahwa pada kelompok siswa yang terpapar oleh Program sekolah sehat, sikap dipengaruhi oleh variabel sosialisasi dari keluarga/orang tua dan sosialisasi iklan TV. Sikap tidak berpengaruh signifikan terhadap perilaku menyikat gigi. Perilaku menyikat gigi anak dipengaruhi secara signifikan oleh sosialisasi dari sekolah. Sementara itu, perilaku menyikat gigi pada kelompok siswa yang belum terpapar oleh Program sekolah sehat dipengaruhi oleh variabel sosialisasi iklan TV.
\end{abstract}

Kata kunci: iklan TV, keluarga, perilaku menyikat gigi, sikap, teman sebaya

\section{Influence of Socialization Agents and TV Advertisements on Attitude and Toothbrushing Behavior of Elementary School Students}

\begin{abstract}
This study aims to analyze the influence of socialization from peers, family / parents, schools, and television advertisements on the attitude and behavior of brushing teeth. The study was conducted in two groups of fifth grade elementary school students in South Tangerang who had been exposed and who had not been exposed to a healthy school program selected using multistage sampling. The total number of respondents was 240 students from four different schools with each group consisting of 120 students from two schools selected using the quota sampling approach. Data was collected by self-reporting techniques and analyzed using descriptive analysis, different tests, and Structural Equation Modeling-Partial Least Square (SEM-PLS). The results showed a significant difference between the two groups of students on socialization variables from peers, family/parents, socialization of TV ads, attitudes, and brushing behavior. The results showed that in the group of students exposed to healthy school programs, attitudes were influenced by variables of socialization from family/parents and TV ads socialization. Attitudes didn't have a significant effect on toothbrushing behavior. Child's toothbrushing behavior was significantly influenced by socialization from school. Meanwhile, toothbrushing behavior in groups of students who had not been exposed to a healthy school program was influenced by the TV advertisements socialization.
\end{abstract}

Keywords: attitude, family, peers, TV advertisements, toothbrushing behavior

\section{PENDAHULUAN}

Seiring dengan meningkatnya populasi kelas menengah di Indonesia, gaya hidup sehat juga semakin meningkat. Peningkatan ini ditandai dengan semakin maraknya kemunculan pusat kebugaran dan semakin berkembangnya gaya makanan sehat. Perkembangan gaya hidup sehat tersebut tidak diikuti dengan perhatian dalam menjaga kesehatan gigi dan mulut. Hal ini terbukti sebanyak 75 persen penduduk Indonesia pernah mengalami riwayat karies gigi dengan tingkat kerusakan gigi sebesar 5 gigi setiap orang dan jumlah penduduk yang melakukan perawatan gigi juga masih rendah yaitu sekitar tujuh persen (Kemenkes, 2012). 
Kondisi kesehatan gigi dan mulut di Indonesia perlu mendapatkan perhatian serius dari berbagai pihak karena prevalensi penduduk dengan masalah gigi dan mulut hingga saat ini cenderung meningkat. Hasil Riskesdas (2013) menunjukkan persentase penduduk dengan masalah gigi dan mulut meningkat menjadi 25,9 persen atau lebih tinggi sebesar 2,3 persen dibandingkan dengan hasil Riskesdas sebelumnya. Jumlah penduduk yang menyikat gigi di waktu yang tepat masih sangat rendah yaitu sebesar 2,3 persen dan rasio kerusakan gigi pun masih belum berubah.

Perawatan gigi sebenarnya dapat dilakukan dengan pembiasaan secara teratur dan disiplin dalam menyikat gigi yaitu pada waktu pagi hari setelah sarapan dan malam hari sebelum tidur (Kemenkes, 2012). Kenyataannya, sebagian besar masyarakat Indonesia masih acuh dengan anjuran tersebut, sehingga dibutuhkan upaya sosialisasi sejak usia dini. Bloom, Iwata, Fritz, Roscoe, dan Carreau (2011) menyebutkan usia pendidikan terbaik untuk anak sebelum mencapai usia 14 tahun. Dengan demikian, upaya pemberian berbagai jenis edukasi dan sosialisasi pada anak penting untuk dilakukan sebagai upaya untuk meningkatkan pengetahuan serta kesadaran dalam bersikap dimasa depannya.

Proses sosialisasi terhadap anak dapat dilakukan melalui dukungan dari banyak pihak yang dikenal dengan istilah agen sosialisasi. Menurut Kerrane dan Hogg (2013) dan juga Ahluwalia dan Sanan (2016), agen sosialisasi terdiri atas keluarga (orang tua), teman sebaya, sekolah dan media informasi. Keluarga merupakan agen sosialisasi yang paling berpengaruh terhadap anak dalam peningkatan keterampilan, pengetahuan, dan nilai-nilai (Viswanathan, Childers, \& Moore, 2000). Huidobro dan Mendenhall (2015) menyatakan bahwa keluarga memberikan orientasi yang baik terhadap aktivitas peningkatan kesehatan. Peran orang tua dapat meningkatkan sikap dan perilaku hidup sehat dari anak (Berliana \& Pradana, 2016; Bozorgmehr, Hajizamani, \& Malek Mohammadi, 2013).

Kegiatan sosialisasi juga dapat dilakukan di sekolah dengan cara melibatkan guru dan teman sebaya. Guru berperan penting dalam meningkatkan perilaku siswa. Hal ini diperkuat oleh Blazar dan Kraft (2017) dan juga Irwandi, Ufatin, dan Sultoni (2016) yang menyebutkan bahwa guru berperan penting dalam mengembangkan sikap dan perilaku siswa menjadi lebih baik. Selain guru, teman sebaya juga berperan dalam dalam meningkatkan perilaku siswa. Tamara (2016) memaparkan bahwa teman sebaya memberikan pengaruh terhadap pembentukan sikap seseorang dalam berkehidupan. Teman sebaya ini juga mampu meningkatkan perilaku hidup sehat pada siswa, khususnya dalam menyikat gigi. Hal ini didukung oleh temuan Arianto (2017) yang menyebutkan bahwa teman sebaya berpengaruh terhadap perubahan dalam aktivitas menyikat gigi.

Selain keluarga dan sekolah, media juga termasuk dalam agen sosialisasi yang dapat memberikan peran dalam mengembangkan dan memengaruhi sikap individu. Fan dan Li (2010) menyatakan adanya hubungan yang kuat antara tumbuhnya sikap positif anak dengan intensitas iklan televisi yang ditonton. Penelitian mengenai peran dan pengaruh iklan TV terhadap sikap dan perilaku anak secara umum telah dilakukan oleh Braun-LaTour dan LaTour (2004); Bakir dan Palan, (2010), Kashif, Ayyaz, \& Basharat (2014); Pagla dan Brennan (2014).

Salah satu perusahaan di Indonesia yang sudah memperhatikan pentingnya sosialisasi menyikat gigi dengan baik dan sesuai aturan sejak usia dini adalah PT. XYZ melalui produk pasta gigi $X$. Perusahaan ini ikut berperan dan berkontribusi aktif dalam meningkatkan kesadaran serta kualitas kesehatan gigi masyarakat. Sejak tahun 2009 PT. XYZ meluncurkan kampanye sikat gigi pagi dan malam yang didasari dari masih rendahnya kesadaran menyikat gigi minimal dua kali sehari pada masyarakat (PT XYZ, 2009). Sosialisasi dilakukan di sekolah dasar dengan tujuan untuk menciptakan kesadaran siswa akan kebersihan gigi dan mulut. Untuk menyukseskan acara tersebut, perusahaan merekrut guru dan dokter kecil untuk menjadi kader kesehatan gigi dan mulut di sekolah yang diharapkan mampu membangun kesadaran siswa melalui perilaku menyikat gigi pagi dan malam dengan cara yang tepat. PT. $X Y Z$ juga melakukan penyebaran pesan edukatif melalui media advertising pada sejumlah channel yang beragam. Menurut Ikaryati (2016), PT. XYZ dalam beriklan selalu mengutamakan aktivitas penyadaran tentang pentingnya menyikat gigi secara benar dan teratur.

Selain teknik menyikat gigi, Creeth et al., (2016) dalam penelitiannya menyebutkan kombinasi antara durasi dan takaran pasta gigi yang tepat dapat meningkatkan perbaikan kekerasan permukaan gigi, penyerapan 
fluoride pada enamel gigi dan ketahanan gigi terhadap asam. Namun penggunaan pasta gigi per kapita di Indonesia tercatat masih belum memenuhi standar anjuran dari pasta gigi $X$ dalam penggunaan pasta gigi dengan minimal penggunaannya dari ujung bulu depan sikat gigi hingga ke bulu belakang sikat gigi atau setara dengan 1 gram. Selama kurun waktu tahun 2007-2010 rata-rata konsumsi pasta gigi masyarakat potensial di Indonesia tidak pernah mencapai 1 gram per harinya (ICN, 2011). Hal ini di satu sisi menunjukkan masih rendahnya kesadaran menggunakan takaran pasta gigi yang tepat, di sisi lain menunjukkan besarnya potensi pasar pasta gigi yang belum tergarap.

Perilaku menyikat gigi pada anak seharusnya dilakukan dan mulai dibiasakan dalam aktivitas sehari-hari. Kemampuan untuk menyikat gigi yang baik dan benar merupakan faktor penting dalam menjaga dan merawat gigi dengan baik. Hal tersebut diperkuat oleh Houwink (1994) yang menyatakan bahwa keberhasilan menyikat gigi juga dipengaruhi oleh faktor penggunaan alat, metode menyikat gigi, serta frekuensi dan waktu menyikat gigi yang tepat.

Berdasarkan pemaparan tersebut, kajian mengenai pengaruh agen sosialisasi dan sikap atas perilaku terhadap perilaku menyikat gigi pada anak sekolah dasar diperlukan. Perbedaan penelitian ini dibandingkan dengan penelitian sebelumnya terletak pada penggunaan iklan TV sebagai variabel agen sosialisasi, segregasi responden yang berasal dari sekolah yang terpapar program sekolah sehat dengan yang berasal dari sekolah yang belum terpapar, dan juga penggunaan sikap atas perilaku sebagai variabel intervening dalam mempengaruhi perilaku karena sikap diyakini berpengaruh terhadap perilaku (Jain, 2014). Penelitian ini bertujuan untuk menganalisis perbedaan agen sosialisasi, sikap atas perilaku, dan perilaku menyikat gigi pada kelompok terpapar dan belum terpapar. Penelitian ini juga bertujuan untuk menganalisis pengaruh agen sosialisasi terhadap sikap atas perilaku pada kelompok terpapar dan belum terpapar. Selain itu, penelitian ini bertujuan untuk menganalisis pengaruh agen sosialisasi dan sikap atas perilaku terhadap perilaku menyikat gigi pada kelompok terpapar dan belum terpapar.

\section{METODE}

Penelitian ini merupakan penelitian kuantitatif dengan menggunakan pendekatan asosiatif yang bertujuan untuk menganalisis pengaruh agen sosialisasi dan sikap atas perilaku terhadap perilaku menyikat gigi. Penelitian ini dilakukan di Sekolah Dasar wilayah Tangerang Selatan sejak bulan Juni sampai dengan bulan Agustus tahun 2018. Sekolah tersebut dipilih sebagai lokasi penelitian karena wilayah tersebut merupakan salah satu yang paling akhir mendapatkan program sekolah sehat dari pasta gigi $X$.

Responden dalam penelitian ini adalah siswa kelas $\mathrm{V}$ dari empat sekolah dasar yang dipilih berdasarkan kriteria yang sudah terpapar atau belum terpapar program sekolah sehat pasta gigi di Indonesia. Teknik yang digunakan dalam penentuan sampel adalah multistage sampling. Tahap pertama dan kedua digunakan teknik purposive sampling, sebuah pengambilan sampel dengan pertimbangan tertentu dengan tujuan agar sampel yang diambil sesuai dengan sifat dan karakteristik yang telah ditentukan. Pada tahap pertama populasi sekolah dikelompokkan menjadi dua, hal ini dilakukan karena diduga terdapat perbedaaan nyata antara sekolah yang sudah mendapatkan program sekolah sehat dan yang belum mendapatkan program. Tahap kedua dilakukan pengelompokan status negeri dan swasta dari masing-masing sekolah yang sudah dan belum terpapar. Selanjutnya diambil sekolah mana yang terpilih dengan menggunakan teknik simple random sampling. Hasilnya adalah sekolah yang terpilih dari yang terpapar terdiri atas satu SD negeri dan satu SD swasta yaitu SDN $X$ dan SDI $X$, begitu juga dengan sekolah yang belum terpapar terdiri atas satu SD negeri dan satu SD swasta yaitu SDN Y dan SDI Y. Dari setiap SD tersebut diambil 60 responden dengan menggunakan teknik purposive sampling sehingga total responden ber-jumlah 240 siswa. Penentuan pengambilan sampel didasari John (1999) yang membagi usia anak menjadi beberapa tahapan yaitu perseptual di usia 3-7 tahun, tahapan analisis di usia 7-11 tahun, dan tahapan reflektif di usia 11-16 tahun dengan kemampuan kognitif dan sosial yang semakin baik. Selanjutnya diambil usia dalam kategori transisi anak ke remaja awal yang masuk dalam tahapan reflektif yaitu kelas $\mathrm{V}$ dengan rentang usia 11-12 tahun.

Data yang digunakan adalah data primer yang terdiri atas karakteristik responden, agen sosialisasi, sikap terhadap perilaku, dan perilaku menyikat gigi. Pengumpulan data dilakukan dengan cara self administer yang dipandu oleh enumerator dengan menggunakan kuesioner terstruktur. Jenis pertanyaan yang digunakan adalah pertanyaan tertutup, 
responden hanya dibatasi pada beberapa alternatif jawaban yang sudah disediakan dalam kuesioner.

Agen sosialisasi dalam penelitian ini terdiri atas teman sebaya, keluarga/orang tua, sekolah/ guru, dan iklan TV. Teman sebaya didefinisikan sebagai teman yang saling berinteraksi dan memengaruhi sikap dan perilaku satu sama lain. Sosialisasi teman sebaya diukur dengan menggunakan tujuh indikator yang diacu dari Santosa (2006). Sosialisasi keluarga/orang tua diukur dengan menggunakan sebelas indikator yang diacu dari Hyoscyamina (2011). Sosialisasi sekolah/guru diukur dengan menggunakan enam indikator yang diacu dari Danim (2011). Selanjutnya, sosialisasi Iklan TV diukur dengan enam indikator yang diacu dari Briawan, Ekayanti, dan Koerniawati (2014).

Sikap atas perilaku didefinisikan sebagai kesiapan antara respon (positif atau negatif) yang muncul akibat beberapa hal yang memengaruhi. Sikap dalam penelitian ini menjadi variabel intervening. Sikap diukur dengan menggunakan enam indikator yang diacu dari Azwar (2007). Selanjutnya, perilaku menyikat gigi didefinisikan sebagai tingkah laku yang menjadi kebiasaan dalam menyikat gigi memiliki empat indikator yang diacu dari Joanna (2006).
Instrumen yang digunakan dalam penelitian ini menggunakan skala Likert dengan skala 1 sampai dengan 5. Skala tersebut merupakan tingkatan atau derajat persetujuan atau kesesuaian responden atas pernyataan atau pertanyaan yang diberikan. Angka 1 menyatakan "sangat tidak setuju" dan angka 5 menyatakan "sangat setuju".

Data yang sudah dikumpulkan selanjutnya dianalisis dengan menggunakan analisis deskriptif, uji beda, dan analisis Partial Least Square (PLS). Analisis deskriptif yaitu sebuah metode yang berusaha untuk mendeskripsikan, menginterpretasikan sesuatu, misalnya kondisi atau hubungan yang ada, pendapat yang berkembang, proses yang sedang ber-langsung, akibat atau efek yang terjadi atau tentang kecenderungan yang sedang ber-langsung (Sukmadinata, 2006). Uji beda digunakan untuk menganalisis perbedaan persepsi antar setiap variabel penelitian berdasarkan kelompok yang sudah terpapar atau belum terpapar program sekolah sehat pasta gigi di Indonesia. Pada analisis Partial Least Square (PLS) data primer yang diperoleh dari para responden penelitian diolah dengan menggunakan PLS yang merupakan jenis SEM berbasis variance yang diciptakan untuk mengatasi masalah yang ditimbulkan oleh SEM berbasis covariance. Model Hybrid SEM disajikan pada Gambar 1.

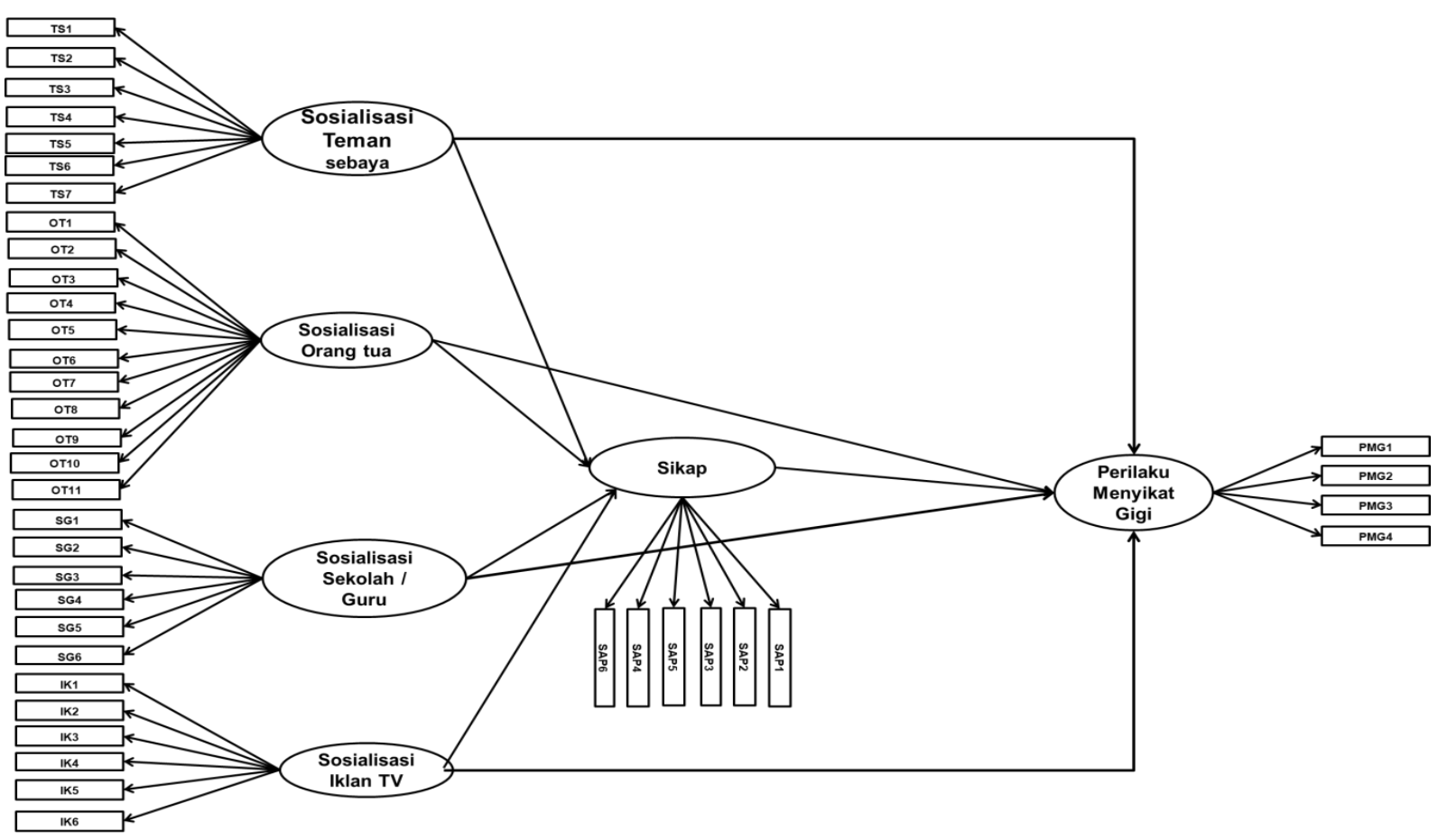

Gambar 1 Model Hybrid SEM 


\section{HASIL}

\section{Karakteristik Responden}

Responden dalam penelitian ini dibagi dalam dua kelompok yaitu kelompok yang sudah terpapar atau belum terpapar program sekolah sehat pasta gigi di Indonesia. Persentase tertinggi responden dari kelompok yang sudah dan belum terpapar program sekolah sehat pasta gigi di Indonesia dalam penelitian ini berjenis kelamin laki-laki (Tabel 1). Persentase tertinggi untuk pekerjaan ayah dari responden baik kelompok yang sudah terpapar atau belum terpapar program sekolah sehat pasta gigi di Indonesia adalah karyawan swasta, sedangkan pekerjaan ibu untuk kedua kelompok tersebut adalah ibu rumah tangga.

\section{Agen Sosialisasi}

Sosialisasi Teman Sebaya. Setengah responden pada sekolah terpapar tidak menyetujui jika teman sebagai sumber informasi $(52,7 \%)$ dan teman diskusi tentang menyikat gigi $(49,7 \%)$, kondisi ini berbeda dengan responden dari sekolah belum terpapar yang menyetujui jika teman sebagai sumber informasi $(51,4 \%)$ dan teman diskusi tentang menyikat gigi (52,7\%). Kedua kelompok sekolah menyatakan mengolok teman yang belum menyikat gigi merupakan hal tidak baik. Responden dari kedua kelompok menyetujui jika perilaku teman menyikat gigi dua kali sehari, teman menyikat gigi di waktu yang tepat, dan termotivasi menyikat gigi. Kedua kelompok sekolah juga memperlihatkan responden pada sekolah terpapar tidak mau meniru cara teman menyikat gigi sementara pada sekolah belum terpapar mau meniru. Hasil tersebut menunjukkan bahwa responden dari sekolah terpapar memiliki tingkat pengetahuan cara menyikat gigi yang baik dan sesuai dibandingkan dengan responden pada sekolah yang belum terpapar yang merasa tidak terlalu membutuhkan informasi, diskusi, dan contoh dari teman sebaya di lingkungan sekolah.

Sosialisasi Orang tua. Hasil penelitian secara umum menunjukkan tingkat persetujuan responden sekolah yang terpapar maupun yang belum terpapar terhadap keseluruhan indikator yang ada sangat tinggi walaupun pada kelompok sekolah terpapar terdapat tingkat ketidaksetujuan responden pada tiga indikator yaitu orang tua menjadi sumber informasi $(52,1 \%)$, orang tua sikat gigi dua kali sehari $(50,0 \%)$, dan orang tua sikat gigi tepat waktu $(60,3 \%)$.
Tabel 1 Sebaran responden berdasarkan karakteristik dan paparan sosialisasi

\begin{tabular}{lcc}
\hline Kategori & $\begin{array}{c}\text { Terpapar } \\
(\%)\end{array}$ & $\begin{array}{c}\text { Belum } \\
\text { Terpapar (\%) }\end{array}$ \\
\hline Jenis Kelamin & & \\
Laki-laki & 60,0 & 53,0 \\
Perempuan & 40,0 & 47,0 \\
\hline Pekerjaan Ayah & & \\
Aparatur Sipil & 27,8 & 20,9 \\
Negara & 58,3 & 73,9 \\
Karyawan Swasta & 10,4 & 3,5 \\
Profesional & 3,5 & 1,7 \\
Wirausaha & & \\
\hline Pekerjaan lbu & & 5,2 \\
Aparatur Sipil & 9,6 & 15,7 \\
Negara & 28,7 & 1,7 \\
Karyawan Swasta & 2,2 & 0,0 \\
Profesional & 5,2 & 77,4 \\
Wirausaha & 1,7 & \\
lbu Rumah Tangga & 54,8 & \\
\hline
\end{tabular}

Sosialisasi Sekolah. Hasil menggambarkan bahwa responden pada kedua kelompok menyetujui keenam indikator tentang peran sekolah/guru dalam menyediakan sarana dan memberikan sosialisasi dengan tingkat persetujuan rata-rata lebih dari 50,0 persen, walaupun terdapat dua indikator di kelompok sekolah belum terpapar yang memiliki tingkat persetujuan rendah yaitu sekolah menyediakan tempat menyikat gigi (36,5\%) dan guru aktif mengecek siswa yang menyikat gigi $(35,3 \%)$. Dibutuhkan adanya peningkatan penyediaan sarana dan prasarana yang mendukung program untuk menyikat gigi. Selain itu, guru diharapkan dapat berperan aktif dalam memonitor kebersihan gigi siswa.

Sosialisasi Iklan TV. Responden dari kedua kelompok sekolah menyetujui pernah melihat iklan TV sikat gigi, merasa iklan TV penting dalam memberikan informasi mengenai sikat gigi, waktu sikat gigi yang tepat, cara yang benar, dan menyadarkan untuk sikat gigi secara teratur. Hasil penelitian menunjukkan bahwa 55,1 persen responden pada kelompok sekolah terpapar tidak menyetujui jika iklan TV dapat mengingatkan untuk menyikat gigi. Akan tetapi, 47,5 persen responden pada kelompok sekolah belum terpapar menyetujui jika iklan TV dapat mengingatkan mereka untuk menyikat gigi. Hasil ini memperlihatkan bahwa program sekolah sehat salah satu merk pasta gigi di Indonesia pada responden sekolah yang terpapar berhasil memberikan tingkat kesadaran dan pemahaman yang lebih baik terhadap iklan TV yang ditayangkan dibandingkan dengan responden sekolah yang belum terpapar. Selain itu, responden dari kelompok 
sekolah terpapar juga memiliki kesadaran menyikat gigi yang lebih tinggi sehingga tidak merasa perlu diingatkan oleh iklan TV.

\section{Sikap terhadap Perilaku}

Hasil penelitian menunjukkan responden pada sekolah terpapar setuju atas seluruh indikator dari sikap. Sementara pada responden sekolah belum terpapar walaupun mereka mempunyai keinginan untuk dapat menyikat gigi dengan benar, tepat waktu dan paham manfaat yang didapat dari menyikat gigi, tetapi masih kurang menyukai rutinitas menyikat gigi (tingkat persetujuan 30,0\%) dan masih menganggap rutinitas menyikat gigi cukup membuang waktu (tingkat persetujuan 11,0\%). Kedua hal ini masih perlu dibina secara rutin dan berkelanjutan untuk menumbuhkan kesadaran menyikat gigi secara teratur.

\section{Perilaku Menyikat Gigi}

Responden dari sekolah terpapar telah berperilaku menyikat gigi dengan baik dan benar khususnya pada kebiasaan menyikat gigi $(45,3 \%)$ dan dosis pasta gigi yang digunakan sepanjang bulu sikat $(50,8 \%)$, sementara pada sekolah belum terpapar belum dapat menunjukkan perilaku tersebut. Berdasarkan metode menyikat gigi yang tepat digunakan, persentase pada kelompok terpapar $(48,0 \%)$ lebih tinggi dibandingkan pada kelompok yang belum terpapar $(37,0 \%)$. Informasi mengenai perilaku menyikat gigi yang benar dan teratur juga dipengaruhi oleh pihak yang memberi informasi dan mengajarkan. Siswa sekolah terpapar memperoleh sumber informasi pertama mengenai menyikat gigi dari ayah dan ibu, sehingga orang tua berperan penting dalam kesehatan gigi anak. Sementara siswa dari sekolah belum terpapar mengetahui informasi menyikat gigi dari ibu saja. Berdasarkan hasil dari kedua sekolah menggambarkan bahwa peran orang tua terutama ibu penting dalam memberikan informasi mengenai menyikat gigi yang baik dan teratur. Selain orang tua, terdapat pihak luar (produsen pasta gigi) yang datang sekolah untuk memberikan informasi tentang menyikat gigi. Pada sekolah terpapar pihak luar datang ke sekolah lebih dari enam bulan yang lalu. Sekolah juga berperan dalam menyadarkan kesehatan gigi dan mulut dengan pemanfaat fasilitas sekolah Unit Kesehatan Sekolah (UKS), tetapi peran UKS pada kedua kelompok sekolah belum optimal.

Iklan pasta gigi di televisi juga berperan meningkatkan kesadaran menjaga kesehatan gigi dan mulut. Pada kedua kelompok sekolah, merek produk dan monster gigi menjadi hal yang mendominasi ingatan siswa. Di kelompok sekolah terpapar, merek produk $(44,8 \%)$ dan monster gigi $(32,7 \%)$. Pada kelompok sekolah belum terpapar, merek produk $(39,8 \%)$ dan monster gigi $(44,6 \%)$. Dari sisi merek pasta gigi yang sering diingat siswa, kedua kelompok sekolah tersebut memperlihatkan pasta gigi $X$ yang sering diingat siswa dengan persentase lebih dari 90,0 persen.

\section{Hasil Analisis Uji Beda Variabel}

Hasil uji beda menunjukkan adanya perbedaan nyata pada lima variabel dengan menggunakan nilai signifikansi $(p>0,10)$ yaitu sosialisasi teman, sosialisasi orang tua, sosialisasi iklan TV, sikap, dan perilaku. Pengaruh sosialisasi teman di sekolah terpapar lebih kecil dibandingkan dengan pengaruh teman di sekolah belum terpapar. Hal ini disebabkan oleh siswa pada sekolah terpapar rata-rata memiliki tingkat pengetahuan yang sama tentang pentingnya menjaga kesehatan gigi. Adanya perbedaan nyata perhatian orang tua pada kedua kelompok pada sekolah yang terpapar memiliki nilai rata-rata yang lebih rendah. Tingkat independensi yang dilatarbelakangi tingkat pengetahuan dan perilaku menyikat gigi yang lebih baik dari anak dapat membuat orang tua mengurangi tingkat monitoring kepada anak. Sosialisasi iklan berpengaruh pada siswa sekolah yang terpapar karena telah mengerti dengan benar pentingnya menjaga kesehatan gigi dan mulut. Sikap dan perilaku menyikat gigi juga memiliki perbedaan nyata antara siswa pada sekolah yang telah terpapar dengan tidak terpapar, hal ini jelas tergambarkan melalui cara siswa menyikat gigi yang lebih baik pada sekolah terpapar.

\section{Analisis Partial Least Square}

Composite Reliability. Setiap variabel memiliki nilai composite reliability lebih dari 0,6 , sehingga dapat dikatakan setiap variabel di kedua model dinyatakan reliabel (Tabel 2).

Tabel 2 Composite Reliability

\begin{tabular}{lcc}
\hline Variabel Laten & Terpapar & $\begin{array}{c}\text { Belum } \\
\text { Terpapar }\end{array}$ \\
\hline Sosialisasi iklan TV & 0,833 & 0,852 \\
Sosialisasi teman & 0,847 & 0,862 \\
Sosialisasi orang tua & 0,837 & 0,857 \\
Sosialisasi sekolah & 0,820 & 0,874 \\
Sikap & 0,730 & 0,762 \\
Perilaku & 0,680 & 1,000 \\
\hline
\end{tabular}


Tabel 3 Hasil uji hipotesis

\begin{tabular}{lrrrrrr}
\hline \multirow{2}{*}{ Variabel } & \multicolumn{4}{c}{ Terpapar } & \multicolumn{2}{c}{ Belum Terpapar } \\
\cline { 2 - 8 } & $\begin{array}{c}\text { Loading } \\
\text { Factor }\end{array}$ & T-Stat & Keterangan & $\begin{array}{c}\text { Loading } \\
\text { Factor }\end{array}$ & T-Stat & Keterangan \\
\hline Sosialisasi Teman $\rightarrow$ Sikap & 0,009 & 0,058 & Tidak signifikan & $-0,006$ & 0,038 & Tidak signifikan \\
Sosialisasi Teman $\rightarrow$ Perilaku & $-0,226$ & 1,163 & Tidak signifikan & $-0,113$ & 0,695 & Tidak signifikan \\
Sosialisasi Orang tua $\rightarrow$ Sikap & 0,343 & $2,533^{*}$ & Signifikan & 0,231 & 1,466 & Tidak signifikan \\
Sosialisasi Orang tua $\rightarrow$ Perilaku & 0,12 & 0,812 & Tidak signifikan & 0,055 & 0,309 & Tidak signifikan \\
Sosialisasi Sekolah $\rightarrow$ Sikap & 0,048 & 0,364 & Tidak signifikan & 0,182 & 1,389 & Tidak signifikan \\
Sosialisasi Sekolah $\rightarrow$ Perilaku & 0,353 & $2,088^{*}$ & Signifikan & 0,261 & 1,880 & Tidak signifikan \\
Sosialisasi Iklan TV $\rightarrow$ Sikap & 0,288 & $2,381^{*}$ & Signifikan & 0,322 & $3,053^{*}$ & Signifikan \\
Sosialisasi Iklan TV $\rightarrow$ Perilaku & $-0,196$ & 1,410 & Tidak signifikan & $-0,199$ & 1,799 & Tidak signifikan \\
Sikap $\rightarrow$ Perilaku & 0,169 & 0,931 & Tidak signifikan & $-0,004$ & 0,028 & Tidak signifikan \\
\hline
\end{tabular}

Keterangan:*signifikan pada t hitung $>1,96$

Pengujian Inner Model. Pengujian pertama pada inner model adalah mengevaluasi persentase variance yang disebut juga sebagai $\mathrm{R}^{2} \quad$ (R-square), yang digunakan untuk menggambarkan sebuah model yang dirancang dengan mengombinasi-kan beberapa variabel yang dapat menggambarkan kondisi sebenarnya. Pada kelompok terpapar, sikap memiliki nilai $R$ Square sebesar 0,303 dan nilai adjusted square sebesar 0,278 dan perilaku memiliki nilai $R$ Square sebesar 0,280 dan nilai adjusted square sebesar 0,089 . Sementara itu, pada kelompok belum terpapar, sikap memiliki nilai $R$ Square sebesar 0,367 dan nilai adjusted square sebesar 0,344 dan perilaku memiliki nilai $R$ Square sebesar 0,053 dan nilai adjusted square sebesar 0,018 . Signifikansi model berfungsi untuk melihat pengaruh kuat atau lemahnya dari hubungan antar variabel dan penting dalam rangka memberikan rekomendasi terkait optimalisasi suatu model.

Uji yang selanjutnya dilakukan adalah uji hipotesis. Hipotesis dalam penelitian ini terdiri atas: (1) Sosialisasi teman sebaya berpengaruh nyata terhadap sikap atas perilaku; (2) Sosialisasi keluarga (orang tua) berpengaruh nyata terhadap sikap atas perilaku; (3) Sosialisasi sekolah berpengaruh nyata terhadap sikap atas perilaku; (4)
Sosialisasi iklan televisi berpengaruh nyata terhadap sikap atas perilaku; (5) Teman sebaya berpengaruh nyata terhadap perilaku menyikat gigi; (6) Sosialisasi keluarga (orang tua) berpengaruh nyata terhadap perilaku menyikat gigi; (7) Sosialisasi sekolah berpengaruh nyata terhadap perilaku menyikat gigi; (8) Sosialisasi iklan televisi berpengaruh nyata terhadap perilaku menyikat gigi; dan (9) Sikap atas perilaku berpengaruh nyata terhadap perilaku menyikat gigi. Hasil pengujian hipotesis untuk model struktural kelompok sekolah terpapar dan belum terpapar dapat dilihat pada Tabel 3.

Pada responden dari kelompok sekolah yang terpapar, sosialisasi orang tua dan iklan secara signifikan mempengaruhi perilaku melalui pembentukan sikap, sementara pada sekolah belum terpapar sosialisasi sekolah dan iklan secara signifikan mempengaruhi perilaku melalui pembentukan sikap. Namun tidak ada pengaruah yang signifikan sosialisasi iklan terhadap perilaku melalui sikap pada sekolah terpapar dan belum terpapar. Dapat disimpulkan pada kelompok sekolah terpapar, sikap memediasi variabel sosialisasi orang tua terhadap perilaku menyikat gigi. Pada kelompok sekolah belum terpapar, sikap memediasi variabel sosialisasi sekolah terhadap perilaku menyikat gigi.

Tabel 4 Pengaruh tidak langsung

\begin{tabular}{|c|c|c|c|c|c|c|}
\hline \multirow[b]{2}{*}{ Variabel } & \multicolumn{3}{|c|}{ Terpapar } & \multicolumn{3}{|c|}{ Belum Terpapar } \\
\hline & $\begin{array}{l}\text { Original } \\
\text { Sample }\end{array}$ & T-Stat & Keterangan & $\begin{array}{l}\text { Original } \\
\text { Sample }\end{array}$ & T-Stat & Keterangan \\
\hline $\begin{array}{l}\text { Sosialisasi Teman } \rightarrow \text { Sikap } \rightarrow \\
\text { Perilaku }\end{array}$ & $-0,0002$ & 0,07 & Tidak signifikan & 0,00006 & 0,03 & Tidak signifikan \\
\hline $\begin{array}{l}\text { Sosialisasi Orang tua } \rightarrow \text { Sikap } \rightarrow \\
\text { Perilaku }\end{array}$ & 0,04 & $2,06^{*}$ & Signifikan & 0,01 & 0,45 & Tidak signifikan \\
\hline $\begin{array}{l}\text { Sosialisasi Sekolah } \rightarrow \text { Sikap } \rightarrow \\
\text { Perilaku }\end{array}$ & 0,02 & 0,76 & Tidak signifikan & 0,05 & $2,61^{*}$ & Signifikan \\
\hline $\begin{array}{l}\text { Sosialisasi Iklan TV } \rightarrow \text { Sikap } \rightarrow \\
\text { Perilaku }\end{array}$ & $-0,06$ & $3,36^{*}$ & Signifikan & $-0,06$ & $5,49^{*}$ & Signifikan \\
\hline
\end{tabular}

Keterangan: * signifikan pada t hitung $>1,96$ 


\section{PEMBAHASAN}

Hipotesis pertama dalam penelitian ini adalah "sosialisasi teman sebaya berpengaruh nyata terhadap sikap atas perilaku". Hasil penelitian menunjukkan bahwa sosialisasi teman sebaya tidak berpengaruh signifikan terhadap sikap atas perilaku baik pada responden dari kelompok sekolah yang sudah terpapar maupun pada responden dari kelompok sekolah yang belum terpapar program sekolah sehat pasta gigi di Indonesia. Hasil ini bertolak belakang dengan penelitian yang dilakukan oleh Reitz, Zimmermann, Hutteman, Specht, dan Neyer (2014) yang menyatakan bahwa sikap seseorang dapat berubah akibat pengaruh kelompok teman sebaya.

Hipotesis kedua dalam penelitian ini adalah "sosialisasi keluarga/orang tua berpengaruh nyata terhadap sikap atas perilaku". Pembentukan sikap anak yang baik dapat dimulai dari orang tua, dengan orang tua memiliki pengetahuan dan pemahaman yang cukup baik tentang pentingnya menjaga kesehatan gigi maka dapat mengajarkan ke anaknya dengan optimal. Orang tua diharapkan menjalankan perannya sebagai sumber informasi dalam menanamkan pengetahuan dan memberikan perhatian sehingga diharap-kan dapat membantu dalam menumbuhkan sikap anak (Friedman, 1998). Hasil penelitian menunjukkan bahwa sosialisasi orang tua mempunyai pengaruh yang signifikan terhadap sikap pada kelompok sekolah terpapar, sementara pada kelompok sekolah belum terpapar menunjukkan hasil yang tidak signifikan. Hal ini mendukung temuan Hyoscyamina (2011), ayah dan ibu dapat membantu perkembangan individu anak dalam membentuk sikap dan kepribadiannya. Masni, (2017) juga menyatakan bahwa peran orang tua terhadap sikap anak begitu besar, dan tergambarkan dari perhatian dalam rangka memperkenalkan hal baru, menumbuhkan minat serta mengembangkan potensi diri. Dariyo dan Rahaditya (2017) juga memberikan pendapat yang sama bahwa peran orang tua yang terlibat aktif secara langsung dapat memberikan pengaruh besar terhadap pembentuk sikap dari anak tersebut. Lebih lanjut Eddy dan Mutiara (2015) menyatakan bahwa orang tua memberikan peranan besar terhadap pemeliharan kesehatan gigi, motivasi orang tua keapada anak dalam menyadarkan kebiasaan baik merupakan hal penting yang perlu dipertahankan.

Hipotesis ketiga dalam penelitian ini adalah "sosialisasi sekolah/guru berpengaruh nyata terhadap sikap atas perilaku". Sosialisasi sekolah/guru terhadap sikap juga tidak menunjukkan pengaruh yang signifikan pada kedua kelompok sekolah. Guru sebagai role model yang berperan penting dalam menumbuhkan sikap siswa dalam menyikat gigi. Guru juga membutuhkan pengetahuan mengenai kesehatan gigi dan mulut serta kontinuitas dalam mengajarkan dan mengingat-kan pentingnya menjaga kesehatan gigi dan mulut. Tanpa hal tersebut diatas, sulit mengharapkan sekolah/guru dapat memberikan pengaruh yang signifikan terhadap sikap atas perilaku menyikat gigi. Makmur, Sujana, dan Kinasih (2017) menyebutkan bahwa penjelasan sosialisasi kesehatan yang dilakukan di sekolah dapat memberikan pengaruh terhadap peningkatan pengetahuan siswa.

Hipotesis keempat dalam penelitian ini adalah "sosialisasi iklan TV berpengaruh nyata terhadap sikap atas perilaku". Pengaruh sosialisasi iklan TV terhadap sikap atas perilaku menyikat gigi pada kedua kelompok sekolah terbukti berpengaruh signifikan. Kondisi ini diartikan bahwa iklan menjadi salah satu yang berperan dalam mengubah sikap siswa dalam menyikat gigi. Hal ini didukung hasil penelitian dari Qolbi (2014) yang menjelaskan bahwa iklan dapat memengaruhi sikap seseorang, yang dikuatkan oleh kesesuaian dari iklan yang ditayangkan serta penempatan produk saat iklan berlangsung. Azmi (2018) menjelaskan iklan secara langsung dapat memengaruhi sikap seseorang, namun hal tersebut disampaikan melalui pesan yang jelas.

Hipotesis kelima dalam penelitian ini adalah "sosialisasi teman sebaya berpengaruh nyata terhadap perilaku menyikat gigi". Hasil penelitian menunjukkan bahwa sosialisasi teman sebaya tidak berpengaruh signifikan terhadap perilaku menyikat gigi baik pada responden dari kelompok sekolah yang sudah terpapar maupun pada responden dari kelompok sekolah yang belum terpapar program sekolah sehat pasta gigi di Indonesia. Perilaku menyikat gigi siswa tidak dipengaruhi sosialisasi teman sebaya karena menyikat gigi merupakan aktivitas yang biasanya dilakukan di rumah, sehingga peran teman dalam aktivitas ini kurang optimal. Apabila di sekolah dilakukan aktivitas menyikat gigi bersama maka dapat menjadi salah satu upaya untuk meningkatkan peran teman dalam perilaku menyikat gigi. Hal ini tidak sejalan dengan hasil penelitian Berliana dan Pradana (2016) yang menjelaskan adanya pengaruh signifikan 
dari teman sebaya terhadap perilaku hidup sehat anak.

Hipotesis keenam dalam penelitian ini adalah "sosialisasi keluarga/orang tua berpengaruh nyata terhadap perilaku menyikat gigi". Pengaruh sosialisasi orang tua terhadap perilaku menunjukkan hasil yang tidak signifikan pada kedua kelompok sekolah. Peran orang tua dalam keikutseraan mengajak anak memiliki perilaku menyikat gigi yang baik dan teratur kurang berpengaruh disebabkan masih sedikit perhatian dan intensitas yang dilakukan orang tua dalam mengajak anak. Dalam penelitian ini juga menunjukkan orang tua masih kurang terlatih untuk melakukan pembiasaan mengenai menyikat gigi ke anak. Muthmainnah (2012) dalam penelitiannya menjelaskan bahwa orang tua harus dapat menerapkan sistem pola asuh yang tepat, sehingga anak dapat berperilaku sesuai dengan harapan.

Hipotesis ketujuh dalam penelitian ini adalah "sosialisasi sekolah/guru berpengaruh nyata terhadap perilaku menyikat gigi”. Pengaruh sosialisasi sekolah (guru) terhadap perilaku menyikat gigi pada sekolah yang terpapar menunjukkan adanya pengaruh yang signifikan. Sementara pada kelompok sekolah yang belum terpapar, sekolah tidak memberikan pengaruh yang signifikan terhadap perilaku menyikat gigi. Konsep yang membeda-kan terpapar dan belum terpapar terletak pada sosialisasi yang mengggambarkan adanya peran sekolah dalam memengaruhi sikap dan perilaku siswa. Hal ini sejalan dengan tujuan dari program sekolah sehat pasta gigi $X$ yang mengajak dan menumbuhkan peran aktif dari sekolah beserta elemennya (kepala sekolah, guru, UKS dan murid) dalam menjaga kesehatan khususnya kesehatan gigi dan mulut. Penelitian terkait peranan sekolah yang dilakukan oleh Ridha dan Rusydi (2016) menjelaskan bahwa sekolah memberikan pengaruh besar terhadap perilaku siswa karena sifat dasar sekolah sebagai sarana pendidikan kedua bagi anak setelah orang tua. Sejalan dengan pernyataan Irwandi, Ufatin, dan Sultoni (2016) yang menyebutkan bahwa sekolah memegang peranan penting dalam menumbuhkembangkan sikap dan perilaku sehat para siswa.

Hipotesis kedelapan dalam penelitian ini adalah "sosialisasi iklan TV berpengaruh nyata terhadap perilaku menyikat gigi”. Pengaruh sosialisasi iklan di TV terhadap perilaku menyikat gigi tidak signifikan di kedua kelompok sekolah. Hal ini disebabkan sifat persuasive iklan belum dapat ditangkap dengan baik oleh anak-anak sehingga tidak efektif untuk mengubah perilaku anak. Menurut Ardiansyah, Arifin, dan Fanani (2015) pesan iklan yang baik harus dibuat secara bertahap, dimulai dari menarik perhatian, meningkatkan pemahanan dan sikapnya. Hal ini sebelumnya telah dijelaskan oleh Russel (1996) yang menjelaskan bahwa iklan yang baik harus memperhatikan komponen musik, storyboard, script, endorser, slogan dan logo. Sifat iklan yang hanya berlalu begitu saja, waktu penempatan tayangan dan banyak noise dari iklan lainnya membuat iklan mudah dilupakan oleh anak-anak yang menyaksikan tayangan tersebut. Penempatan iklan harus sesuai keperluannnya, anak-anak di Indonesia mayoritas menonton televisi di waktu Sabtu dan Minggu (Ali, 2014).

Hipotesis kesembilan dalam penelitian ini adalah "sikap berpengaruh nyata terhadap perilaku menyikat gigi”. Pengaruh variabel sikap terhadap variabel perilaku menyikat gigi menunjukkan hasil yang tidak signifikan pada kedua kelompok sekolah. Hal ini bertentangan dengan hasil penelitian Simanjuntak dan Musyifah (2016) yang menyatakan bahwa sikap memengaruhi perilaku. Pada kelompok sekolah yang terpapar walaupun sudah memiliki tingkatan sikap yang lebih baik tetapi belum mampu mendorong anak secara mandiri untuk berperilaku menyikat gigi dengan baik dan benar sehingga masih perlu mendapat dukungan dari sekolah (guru) dan orang tua. Kelompok sekolah yang belum terpapar memiliki tingkatan sikap yang lebih rendah dibandingkan kelompok sekolah terpapar. Sikap yang masih harus ditumbuhkan adalah menyadari besarnya manfaat dari menyikat gigi sehingga diharapkan anak menjadi suka akan rutinitas menyikat gigi dan kegiatan tersebut bukan kegiatan yang sia-sia dan membuang waktu.

\section{SIMPULAN DAN SARAN}

Sosialisasi dari teman sebaya, keluarga/orang tua, sosialisasi iklan TV, sikap, dan perilaku menyikat gigi berbeda signifikan antara responden dari kelompok yang sudah terpapar atau belum terpapar program sekolah sehat pasta gigi di Indonesia. Pada kelompok siswa yang terpapar oleh Program sekolah sehat, sikap dipengaruhi oleh variabel sosialisasi dari keluarga/orang tua dan sosialisasi iklan TV. Sikap tidak berpengaruh signifikan terhadap perilaku menyikat gigi. Perilaku menyikat gigi anak dipengaruhi secara signifikan oleh 
sosialisasi dari sekolah. Sementara itu, perilaku menyikat gigi pada kelompok siswa yang belum terpapar oleh Program sekolah sehat dipengaruhi oleh variabel sosialisasi iklan TV.

Kesadaran masyarakat untuk menjaga kesehatan gigi dan mulut masih rendah. Oleh karenanya, orang tua, sekolah, pemerintah, dan juga perusahaan diharapkan dapat berperan lebih aktif dalam gerakan penyadaran pentingnya menjaga kesehatan gigi dan mulut bahkan dapat menjadikan menyikat gigi yang baik dan benar sebagai gerakan nasional yang dapat membantu akselerasi penyadaran pentingnya menjaga kesehatan gigi dan mulut. Selama ini, perusahaan dalam melaksanakan program sekolah sehat pada satu sekolah hanya sekali saja dengan memberikan bantuan material berupa sikat gigi beserta pasta gigi bagi seluruh siswa, poster, materi presentasi, dan alat peraga gigi sekaligus juga pelatihan yang diberikan kepada perwakilan guru dan murid sehingga diharapkan kedepannya sekolah tersebut bisa secara mandiri dan berkelanjutan dalam melakukan gerakan menjaga kesehatan gigi dan mulut. Untuk selanjutnya, perusahaan diharapkan mampu untuk menjaga keberlangsungan pelaksanaan program dan hubungan komunikasi dengan sekolah-sekolah yang sudah pernah mendapatkan program sekolah sehat dengan memanfaatkan teknologi digital seperti penyediaan website khusus komunitas sekolah yang sudah terpapar program sekolah sehat. Konten website tersebut bisa diisi dengan berita terbaru mengenai pelaksanaan program sekolah sehat di tempat lain, informasi pengetahuan tentang kesehatan gigi dan mulut dan juga alat peraga terbaru yang bisa diunduh untuk kemudian bisa digunakan dalam proses pembelajaran di sekolah. Perusahaan juga dapat berperan dengan cara menyediakan iklan TV yang mendidik terutama untuk kesehatan gigi dan mulut.

\section{DAFTAR PUSTAKA}

Ahluwalia, A. K., \& Sanan, P. (2016). Consumer Awareness and Consumer Activism Among Adolescents: A Socialization Perspective. IUP Journal of Marketing Management, 15(1), 49.

Ali, M. M. (2014). Analisis Isi Iklan Televisi di Indonesia. Humaniora, 5(2), 766-776.

Ardiansyah, L., Arifin, Z., \& Fanani, D. (2015). Pengaruh Daya Tarik Iklan Terhadap Efektivitas Iklan. Jurnal Administrasi
Bisnis (JAB), 23(2), 75-84.

ARIANTO, A. (2017). Peran Orang Tua, Teman, Guru, Petugas Kesehatan Terhadap Perilaku Menggosok Gigi Pada Siswa Sekolah Dasar di Kecamatan Sumberejo. Jurnal Analis Kesehatan, 2(2), 270-275.

Azmi, F. N. (2018). Pengaruh Iklan Televisi terhadap Pengambilan Keputusan Pembelian Konsumen Es Krim Magnum. Jurnal Manajemen Dan Organisasi, 8(2), 119-132.

Azwar, S. (2007). Sikap Manusia Teori dan Pengukurannya, Edisi ke-2. Yogyakarta: Pustaka Pelajar Offset.

Bakir, A., \& Palan, K. M. (2010). How are children's attitudes toward ads and brands affected by gender-related content in advertising? Journal of Advertising, 39(1), $35-48$.

Basharat, S., Kashif, M., \& Ayyaz, M. (2014). TV food advertising aimed at children: qualitative study of Pakistani fathers' views. Asia Pacific Journal of Marketing and Logistics, 26(4), 647-658. https://doi.org/10.1108/APJML-04-20140063

Berliana, N., \& Pradana, E. (2016). Hubungan peran orangtua, pengaruh teman sebaya dengan perilaku hidup bersih dan sehat. Jurnal Endurance: Kajian IImiah Problema Kesehatan, 1(2), 75-80.

Blazar, D., \& Kraft, M. A. (2017). Teacher and teaching effects on students' attitudes and behaviors. Educational Evaluation and Policy Analysis, 39(1), 146-170.

Bloom, S. E., Iwata, B. A., Fritz, J. N., Roscoe, E. M., \& Carreau, A. B. (2011). Classroom application of a trial-based functional analysis. Journal of Applied Behavior Analysis, 44(1), 19-31.

Bozorgmehr, E., Hajizamani, A., \& Malek Mohammadi, T. (2013). Oral health behavior of parents as a predictor of oral health status of their children. ISRN Dentistry, 2013.

Braun-LaTour, K. A., \& LaTour, M. S. (2004). Assessing the long-term impact of a consistent advertising campaign on consumer memory. Journal of Advertising, 33(2), 49-61.

Briawan, D., Ekayanti, I., \& Koerniawati, R. D. (2014). Pengaruh media kampanye sarapan sehat terhadap perubahan pengetahuan, sikap, dan kebiasaan 
sarapan anak sekolah dasar di Kabupaten Bogor. Jurnal Gizi Dan Pangan, 8(2), 115-122.

Creeth, J. E., Kelly, S. A., González-Cabezas, C., Karwal, R., Martinez-Mier, E. A., Lynch, R. J. M., ... Zero, D. T. (2016). Effect of toothbrushing duration and dentifrice quantity on enamel remineralisation: $A n$ in situ randomized clinical trial. Journal of Dentistry, 55, 6167.

Danim, S. (2011). Pengantar Kependidikan Landasan. Teori, Dan Metafora Pendidikan: Bandung Alfabeta.

Dariyo, A., \& Rahaditya, R. R. (2017). Peran Pola Pengasuhan Orangtua Terhadap Sikap Nasionalisme Remaja. Jurnal Provitae, 9(1).

Eddy, F. N. E., \& Mutiara, H. (2015). Peranan Ibu dalam Pemeliharaan Kesehatan Gigi Anak dengan Status Karies Anak Usia Sekolah Dasar. Jurnal Majority, 4(8), 1-6.

Fan, Y., \& Li, Y. (2010). Children's buying behaviour in China: A study of their information sources. Marketing Intelligence \& Planning, 28(2), 170-187.

Friedman, M. M. (1998). Keperawatan keluarga: teori dan praktik. Jakarta: EGC, 177.

Houwink, B. (1994). Ilmu Kedokteran Gigi Pencegahan. Suryo S, penerjemah. Yogyakarta (ID): UGM Press. Terjemahan dari Preventieve tandheelkunde: Op weg naar een doelmatige aanpak.

Huidobro, D. G., \& Mendenhall, T. (2015). Family oriented care: opportunities for health promotion and disease prevention. Journal of Family Medicine and Disease Prevention.

Hyoscyamina, D. E. (2011). Peran keluarga dalam membangun karakter anak. Jurnal Psikologi, 10(2), 144-152.

[ICN] Indonesian Commercial Newsletter [internet]. 2011. [Diakses pada 2018 Februari 10]. Tersedia pada http://www.datacon.co.id/Toiletries2011PastaGigi.html

IKARYATI, P. F. (n.d.). Analisis Diskursus Iklan Pasta Gigi Pepsodent. Paradigma: Jurnal Online Mahasiswa S1 Sosiologi UNESA, 4(1).

Irwandi, S., Ufatin, N., \& Sultoni, S. (2016). Peran Sekolah Dalam Menumbuhkembangkan Perilaku Hidup
Sehat Pada Siswa Sekolah Dasar (Studi Multi Situs Di SD Negeri 6 Mataram dan SD Negeri 41 Mataram Kota Mataram Nusa Tenggara Barat). Jurnal Pendidikan: Teori, Penelitian, Dan Pengembangan, 1(3), 492-498.

Jain, V. (2014). 3D model of attitude. International Journal of Advanced Research in Management and Social Sciences, 3(3), 1-12.

Joanna, A. (2006). CDHA position paper on tooth brushing. Canadian Journal of Dental Hygiene (CJDH), 40(5), 232-248.

John, D. R. (1999). Consumer socialization of children: A retrospective look at twentyfive years of research. Journal of Consumer Research, 26(3), 183-213.

[Kemenkes] Kementerian Kesehatan. (2012). Direktorat Jenderal Bina Upaya Kesehatan. Pedoman Paket Dasar Pelayanan Kesehatan Gigi dan Mulut di Puskesmas. Jakarta

Kerrane, B., \& Hogg, M. K. (2013). Shared or non-shared? Children's different consumer socialisation experiences within the family environment. European Journal of Marketing, 47(3/4), 506-524.

Makmur, M., Sujana, T., \& Kinasih, A. (2017). STRATEGI PROGRAM KESEHATAN PUSKESMAS DI SEKOLAH DASAR. Jurnal IImu Keperawatan Dan Kebidanan, 8(2), 107-133.

Masni, H. (2017). Peran Pola Asuh Demokratis Orangtua Terhadap Pengembangan Potensi Diri Dan Kreativitas Siswa. Jurnal IImiah Dikdaya, 6(1), 58-74.

Muthmainnah, M. (2012). Peran Orang Tua dalam Menumbuhkan Pribadi Anak yang Androgynius Melalui Kegiatan Bermain. Jurnal Pendidikan Anak, 1(1).

Pagla, M., \& Brennan, R. (2014). The development of brand attitudes among young consumers. Marketing Intelligence \& Planning, 32(6), 687-705.

PT. XYZ. (2009). Laporan Tahunan PT. Unilever Indonesia, Tbk.

Qolbi, U. S. (2014). PENGARUH IKLAN TERHADAP SIKAP KONSUMEN (Survei pada Pengunjung yang Pernah Bermain Game Pro Evolution Soccer di Flux Capital Of Entertainment Kecamatan Blimbing Kota Malang). Jurnal Administrasi Bisnis, 10(1).

Reitz, A. K., Zimmermann, J., Hutteman, R., 
Specht, J., \& Neyer, F. J. (2014). How peers make a difference: The role of peer groups and peer relationships in personality development. European Journal of Personality, 28(3), 279-288.

Ridha, A., \& Rusydi, S. R. (2016). Pengaruh Lingkungan Keluarga dan Sekolah terhadap Perilaku Siswa. Tarbawi: Jurnal Pendidikan Agama Islam, 1(1), 52-58. Retrieved from https://journal.unismuh.ac.id/index.php/tar bawi/article/view/356/326

[Riskesdas] Riset Kesehatan Dasar. (2013). Badan Penelitian dan Pengembangan Kesehatan Kementerian Republik Indonesia. Jakarta (ID): Kemenkes

Russel, J.T. (1996). Kleppner's Advertising Procedure Thirteenth Edition. New Jersey (US): Prentice Hall

Santosa, S. (2006). Dinamika Kelompok.
Jakarta: Bumi Aksara.

Simanjuntak, M., \& Musyifah, I. (2016). Online shopping behavior on generation $Y$ in Indonesia. Global Business and Finance Review, 21, 33-45.

Sukmadinata. (2006). Metode Penelitian Kualitatif. Bandung: Graha Aksara.

Tamara, R. M. (2016). Peranan Lingkungan Sosial Terhadap Pembentukan Sikap Peduli Lingkungan Peserta Didik Di Sma Negeri Kabupaten Cianjur. Jurnal Geografi Gea, 16(1), 44-55.

Viswanathan, M., Childers, T. L., \& Moore, E. S. (2000). The measurement of intergenerational communication and influence on consumption: Development, validation, and cross-cultural comparison of the IGEN scale. Journal of the Academy of Marketing Science, 28(3), 406-424. 